Gut, 1977, 18, 721-722

\title{
Effect of carbenoxolone sodium on human gastric acid secretion
}

\author{
J. H. BARON ${ }^{1}$ \\ From the Department of Surgery, Royal Postgraduate Medical School, London
}

SUMMARY Neither basal nor peak acid output changed significantly after treatment for four weeks with carbenoxolone sodium as Biogastrone tablets in patients with gastric ulcer or Duogastrone capsules in patients with duodenal ulcer.

The mechanisms of ulcer healing by carbenoxolone are not fully understood. One of the early controlled trials (Bank et al., 1967) suggested that carbenoxolone may have an inhibitory effect of gastric acid secretion, but later studies have been inconclusive (Table). This problem has, therefore, been re-examined using appropriate preparations of carbenoxolone in patients with gastric ulcer and with duodenal ulcer.

\section{Methods}

\section{SUBJECTS}

Ten patients with gastric ulcer were given carbenoxolone sodium as Biogastrone tablets $100 \mathrm{mg}$ three times a day for four weeks. Ten patients with duodenal ulcer were given Duogastrone capsules $50 \mathrm{mg}$ four times a day for four weeks.

TESTS

Basal and peak acid output after pentagastrin were

${ }^{1}$ Address for correspondence: Dr J. H. Baron, Department of Surgery, Royal Postgraduate Medical School, Hammersmith Hospital, London W12 0HS.

Received for publication 4 March 1977 measured by standard methods (Baron, 1963a). The patient fasted overnight and a nasogastric tube was positioned fluoroscopically in the body of the stomach. The stomach was emptied, and 15-minute collections of gastric juice were then made by continuous pump and intermittent hand suction. After a basal hour pentagastrin, $6 \mu \mathrm{g} / \mathrm{kg}$ was injected intramuscularly, and four further 15-minute collections were made. Volume, $\mathrm{pH}$, and titratable acidity (to pH 7) were measured. Peak acid output ( $\mathrm{mmol} / \mathrm{h}$ ) was calculated by doubling the sum of the two highest consecutive 15-minute periods of acid output after pentagastrin.

Acid tests were done before, and the morning after the end of, the four-week course of treatment with carbenoxolone. The significances of differences were calculated non-parametrically by Wilcoxon's matched-pairs signed-rank test.

\section{Results (Figure)}

The basal and peak acid outputs of the patients with gastric and duodenal ulcer were similar to those previously reported (Baron, 1963b). After treatment with carbenoxolone as Biogastrone basal acid out-

Table Effect of carbenoxolone sodium on human gastric acid secretion

\begin{tabular}{|c|c|c|c|c|c|c|c|c|}
\hline Source & Subjects & $\boldsymbol{n}$ & Drug & $\begin{array}{l}\text { Dose } \\
\text { (mg/day) }\end{array}$ & $\begin{array}{l}\text { Duration } \\
\text { (weeks) }\end{array}$ & $B A O$ & $\begin{array}{l}\text { PAO } \\
\text { (reduction \%) }\end{array}$ & Stimulant \\
\hline Bank et al. (1967) & GU & 11 & Biogastrone & $\left\{\begin{array}{l}300 \\
200\end{array}\right.$ & $\begin{array}{l}1 \\
3\end{array}$ & & 24 & $\begin{array}{l}\text { Augmented } \\
\text { histamine }\end{array}$ \\
\hline & GU & 11 & Placebo & & & & 13 & \\
\hline Cocking and MacCaig (1969) & GU & $\begin{array}{l}16 \\
17\end{array}$ & $\begin{array}{l}\text { Biogastrone } \\
\text { Placebo }\end{array}$ & $\left\{\begin{array}{l}300 \\
150\end{array}\right.$ & $\begin{array}{l}1 \\
4\end{array}$ & & $\begin{array}{l}16 \\
13\end{array}$ & $\begin{array}{l}\text { Augmented } \\
\text { histamine }\end{array}$ \\
\hline Berstad et al. (1970) & $\begin{array}{l}\text { DU } \\
\text { Controls }\end{array}$ & $\left.\begin{array}{l}2 \\
3\end{array}\right\}$ & $\begin{array}{l}\text { Carbenoxolone } \\
\text { Intraduodenal }\end{array}$ & 200 & $2 \mathrm{~min}$ & Inconstant & & \\
\hline Geismar et $a^{\prime}$. (1973) & GU & 13 & Biogastrone & $\left\{\begin{array}{l}300 \\
150\end{array}\right.$ & $\begin{array}{l}1 \\
3\end{array}$ & & $P<\theta .05$ & $\begin{array}{l}\text { Augmented } \\
\text { histamine }\end{array}$ \\
\hline Ottenjann and Rösch (1970) & GU & $\begin{array}{r}11 \\
7\end{array}$ & $\begin{array}{l}\text { Placebo } \\
\text { Biogastrone }\end{array}$ & $\left\{\begin{array}{l}300 \\
150\end{array}\right.$ & $\begin{array}{l}1 \\
3\end{array}$ & NS & NS & \\
\hline $\begin{array}{l}\text { Baas et al. (1975) } \\
\text { Domschke et al. (1975) } \\
\text { Gordon et al. (1975) }\end{array}$ & $\begin{array}{l}\text { Controls } \\
\text { Controls } \\
\text { Controls }\end{array}$ & $\begin{array}{r}6 \\
10 \\
6\end{array}$ & $\begin{array}{l}\text { Biogastrone } \\
\text { Biogastrone } \\
\text { Biogastrone }\end{array}$ & $\begin{array}{l}300 \\
300 \\
300 \\
150\end{array}$ & $\begin{array}{l}1 \\
6 \mathrm{~d} \\
1 \\
2\end{array}$ & $\begin{array}{c}\text { NS } \\
\text { NS } \\
<0.05\end{array}$ & $\begin{array}{l}\text { NS } \\
\text { NS }\end{array}$ & $\begin{array}{l}\text { Pentagastrin } \\
\text { Pentagastrin }\end{array}$ \\
\hline
\end{tabular}




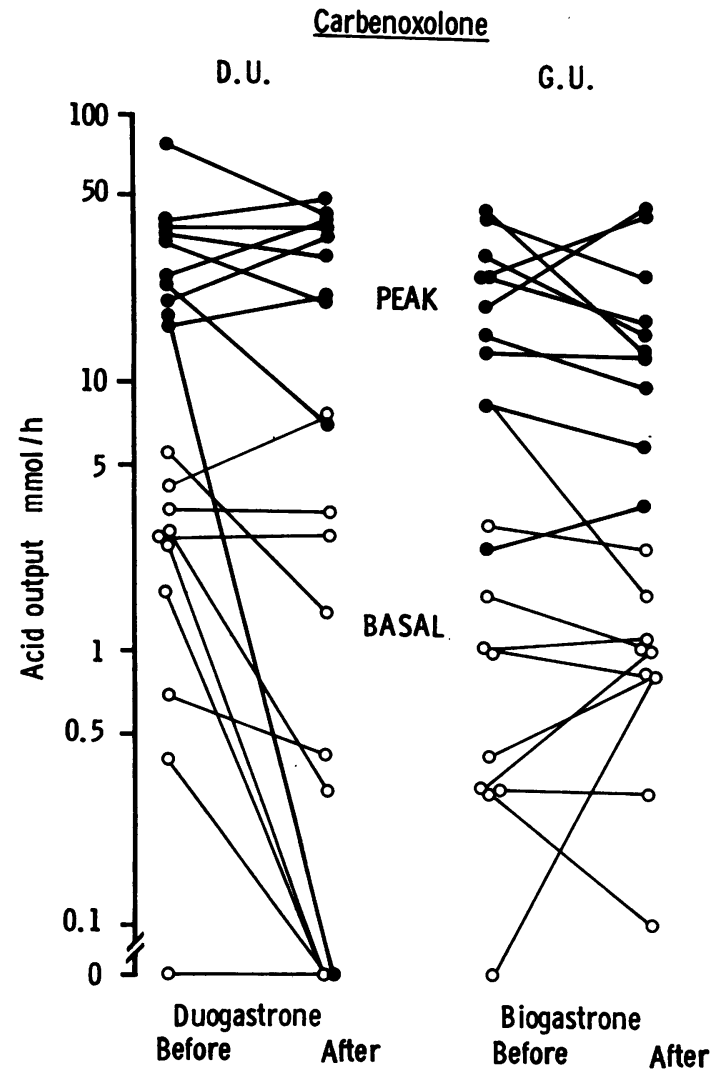

Figure Basal (O) and peak (O) acid output after pentagastrin in 10 patients with duodenal ulcer $(D U)$ before and after a four-week course of Duogastrone $200 \mathrm{mg} /$ day and 10 patients with gastric ulcer $(G U)$ before and after a four-week course of Biogastrone, $300 \mathrm{mg} /$ day. By Wilcoxon matched-pairs signed-ranks test, $\mathrm{P}>0.1$ for each of the four comparisons shown.

put fell in five, and peak acid output in seven, of 10 patients. After treatment with carbenoxolone as Duogastrone basal acid output fell in seven, and peak acid output in five, of 10 patients.

The changes in basal and peak acid output after a four-week course of carbenoxolone in patients with gastric or duodenal ulcer were not statistically significant.

\section{Discussion}

Basal acid output shows obvious variation on repeated tests on the same subject with coefficients of variation over $50 \%$ (Baron 1963a, 1970). Peak acid output has excellent repeatability with coefficients of variation of only 8 to $9 \%$ (Baron 1963a, 1970). On repeated testing over periods of weeks both basal and peak acid output occasionally show distinct spontaneous increases or reductions (Baron, 1970), as in this series of patients treated with carbenoxolone.

Carbenoxolone had no significant systematic effect on basal and peak aspirated acid output, which represents the sum of acid secretion into the stomach minus pyloric loss and neutralisation by saliva and duodenal juice. Admittedly, no allowance was made in the present studies for these three errors, so that it is theoretically possible, though highly unlikely, that carbenoxolone both reduced gastric acid secretion and reduced salivation, pyloric loss, and reflux.

\section{Conclusion}

The absence in this series of any significant changes in basal or peak acid output after carbenoxolone given for four weeks to patients with gastric or duodenal ulcer makes it improbable that carbenoxolone has an inhibitory effect on gastric acid secretion, or that its ulcer-healing effect could be related to inhibition of gastric acid.

\section{References}

Baas, E. U., Sinterhauf, K., Holtermüller, K. H., Noe, G., and Lommer, D. (1975). Der einfluss von Carbenoxolon und deglycyrrhiziniertem Succus liquiritiae auf das Plasma-Cortisol gesunder Probanden. Verhandlugen der Deutschen Gesellschaft fur innere Medizin, 81, 1239-1241.

Bank, S., Marks, I. N., Palmer, P. E. S., Groll, A., and van Eldik, E. (1967). A trial of carbenoxolone sodium in the treatment of gastric ulceration. South African Medical Journal, 41, 297-300.

Baron, J. H. (1963a). Studies of basal and peak acid output with an augmented histamine test. Gut, 4, 136-144.

Baron, J. H. (1963b). An assessment of the augmented histamine test in the diagnosis of peptic ulcer. Gut, 4, 243-253.

Baron, J. H. (1970). Gastric secretion in a healthy man, 1949-1969. Lancet, 2, 547-549.

Berstad, A., Petersen, H., and Myren, J. (1970). The effect of intraduodenal carbenoxolone sodium on gastric and duodenal secretion in man. In Carbenoxolone Sodium, pp. 69-73. Edited by J. H. Baron and F. M. Sullivan. Butterworths: London.

Cocking, J. B., and MacCaig, J. N. (1969). Effect of low dosage of carbenoxolone sodium on gastric ulcer healing and acid secretion. Gut, 10, 219-225.

Domschke, S., Domschke, W., and Demling, L. (1975). Effect of intravenous prednisolone on net ion fluxes across human gastric mucosa : antagonism by carbenoxolone sodium. In Fourth Symposium on Carbenoxolone, pp. 75-86. Edited by F. A. Jones and D. V. Parke. Butterworths: London.

Geismar, P., Mosbech, J., and Myren, J. (1973). A doubleblind study of the effect of carbenoxolone sodium in the treatment of gastric ulcer. Scandinavian Journal of Gastroenterology, 8, 251-256.

Gordon, M. J., O'Brien, P., and Skillman, J. J. (1975). The effect of carbenoxolone on ch anges in canine and human gastric mucosa caused by taurocholate and ethanol. Surgery, 77, 707-713.

Ottenjann, R., and Rösch, W. (1970). Clinical and experimental studies on carbenoxolone sodium. In Carbenoxolone Sodium, pp. 75-81. Edited by J. H. Baron and F. M. Sullivan. Butterworths: London. 